\title{
MANAJEMEN PEMASARAN LEMBAGA AMIL ZAKAT NASIONAL (LAZNAS) STUDI KASUS : BAITUL MAAL HIDAYATULLAH (BMH) PUSAT JAKARTA
}

\author{
Nasrullah*, Kholil Nawawi, Ikhwan Hamdani \\ Universitas Ibn Khaldun Bogor \\ *Email: nasrullah02@gmail.com
}

\begin{abstract}
Abstrak
Baznas menyatakan bahwa potensi zakat ada dikisaran 217 Triliun, tapi yang sampai saat ini dikelola oleh BAZNAS dan LAZNAS hanya berada dikisaran 8 Triliun. Lebarnya gap anatara potensi dan pencapaian menimbulkan pertanyaan bagaimanakah implementasi manajemen pemasaran di lembaga pengelola zakat dan apa yang menyebabkan mereka belum mampu memaksimalkan potensi yang ada. Penelitian ini dilakukan untuk mengenal lebih jauh tentang manajemen pemasaran di lingkungan Lembaga Amil Zakat terkhusus di Baitul Maal Hidayatullah Pusat Jakarta. Penelitian menggonakan metode field research dan table research dengan mengumpulkan data berupa wawancara dan dokumen lembaga. Hasil penelitian mendapati bahwa sebenarnya program-program yang ada di Baitul Maal Hidayatullah sudah berjalan dengan baik, tapi kurangnya kreativitas dan inovasi untuk mengemas program tersebut agar menjadi lebih menarik mengurangi minat para donatur/muzakki untuk menyalurkan lebih banyak dananya ke lembaga tersebut. Terbatasnya tenaga yang tersedia juga berperan atas tidak maksimalnya kinerja pemasaran di lembaga, beban yang terlalu berat dipikulkan pada individu yang berada dilingkup pemasaran membuat mereka tidak begitu leluasa untuk berkreatifitas lebih bebas. Ditambah lagi kurangnya penguasaan tentang ilmu pemasaran yang lebih lanjut semakin menghambat pengembangan pemasaran di Baitul Maal Hidayatullah. Baitul Maal Hidayatullah butuh merekrut lebih banyak tenaga profesional agar beban berlebih yang ditanggung para manajer dan staff pemasaran bisa berkurang dan potensi kreatifitas mereka bisa dimaksimalkan. Dan dilapangan perlu relawan tambahan untuk memberikan pendampingan agar manfaat (dana/bantuan) yang diterima bisa meningkatkan taraf hidup mereka.
\end{abstract}

Kata Kunci: Manajemen Pemasaran, Lembaga Amil Zakat Nasional.

\section{PENDAHULUAN}

Zakat merupakan salah satu pilar dari pilar islam yang lima. Allah SWT telah mewajibkan bagi setiap muslim untuk mengeluarkannya sebagai penyuci harta mereka, yaitu bagi mereka yang telah memiliki harta sampai nishab (batas terendah wajibnya zakat) dan telah lewat atas kepemilikan harta tersebut masa haul (satu tahun bagi harta simpanan dan niaga, atau telah tiba saat memanen hasil pertanian). Di Indonesia dengan kondisi ekonomi saat ini apabila dapat menerapkan sistem zakat dengan baik, maka dapat dipastikan dapat meningkatkan tingkat kesejahteraan bagi masyarakatnya. Contoh nyata keberhasilan 
penerapan sistem pendayagunaan dana ZIS yang baik adalah sistem zakat yang diterapkan di lembaga amil zakat di Malaysia yang dapat mensejahterakan masyarakat sekitarnya.

Rasulullah Saw. pernah mempekerjakan seorang pemuda dari suku Asad, yang bernama Ibnu Lutaibah, untuk mengurus urusan zakat Bani Sulaim. Pernah pula mengutus Ali bin Abi Thalib ke Yaman untuk menjadi amil zakat (Imam Qurthubi,1413H/1993M hal. 113). Muaz bin Jabal pernah diutus Rasulullah Saw. pergi ke Yaman, di samping bertugas sebagai da'i (menjelaskan ajaran Islam secara umum), juga mempunyai tugas khusus menjadi amil zakat (Ismail al-Kahlani al-Shan'ani, 1700:120). Demikian pula yang dilakukan oleh para Khulafaurrasyidin sesudahnya, mereka selalu mempunyai petugas khusus yang mengatur masalah zakat, baik pengambilan maupun pendistribusiannya.

Salah satu faktor penyebab kurang maksimalnya kinerja lembaga zakat adalah kurangnya niat umat muslim untuk berzakat di lembaga zakat, serta rendahnya kepercayaan masyarakat terhadap institusi formal pengelola zakat sehingga menyalurkan zakat dengan cara mandiri (Maulana, 2010). Maka dari itu untuk mengatasi fenomena tersebut tugas dari pengelola zakat adalah mengerti dan memahami perilaku muzakki agar dapat menjaring dana dan mendapatkan kepercayaan dari para muzakki.

\section{KAJIAN PUSTAKA}

\section{Manajemen Pemasaran}

Untuk mengelola proses jual beli diperlukan sejumlah upaya dan keterampilan penting. Seseorang biasanya mahir dalam pembelian untuk memenuhi kebutuhan rumah tangganya. Kadangkala mereka juga melakukan penjualan: penjualan kendaraan mereka, penjualan jasa pribadi mereka. Organisasi lebih profesional dalam menangani proses jual beli itu. Mereka harus menarik sumberdaya dari seperangkat pasar, mengubah sumberdaya itu menjadi produk yang berfaedah, dan menjual produk itu di pasar lainnya. Menurut Philip Kotler (1990:20) definisi tentang manajemen pemasaran adalah:

Manajemen pemasaran adalah analisis, perencanaan, penerapan dan pengendalian terhadap program yang dirancang untuk menciptakan membangun dan mempertahankan pertukaran dan hubungan yang menguntungkan dengan pasar sasaran dengan maksud untuk mencapai tujuan-tujuan organisasi.

\section{Prinsip Pemasaran}

Menurut Warren J. Keegan (1996:6-7) inti dari pemasaran dapat diringkas dalam tiga prinsip dasar. mencapai dua prinsip pertama.

a. Nilai Pelanggan dan Persamaan Nilai : Intisari pemasaran adalah menciptakan nilai pelanggan yang lebih besar dari pada yang diciptakan oleh pesaing. Persamaan nilai, yang ditunjukkan dalam Gambar 1 adalah pedoman dari tugas ini. Seperti yang disarankan dalam persamaan ini, nilai untuk pelanggan dapat 
dinaikkan dengan memperluas atau memperbaiki produk dan/atau manfaat jasa, dengan menurunkan harga, atau gabungan dari unsur ini.

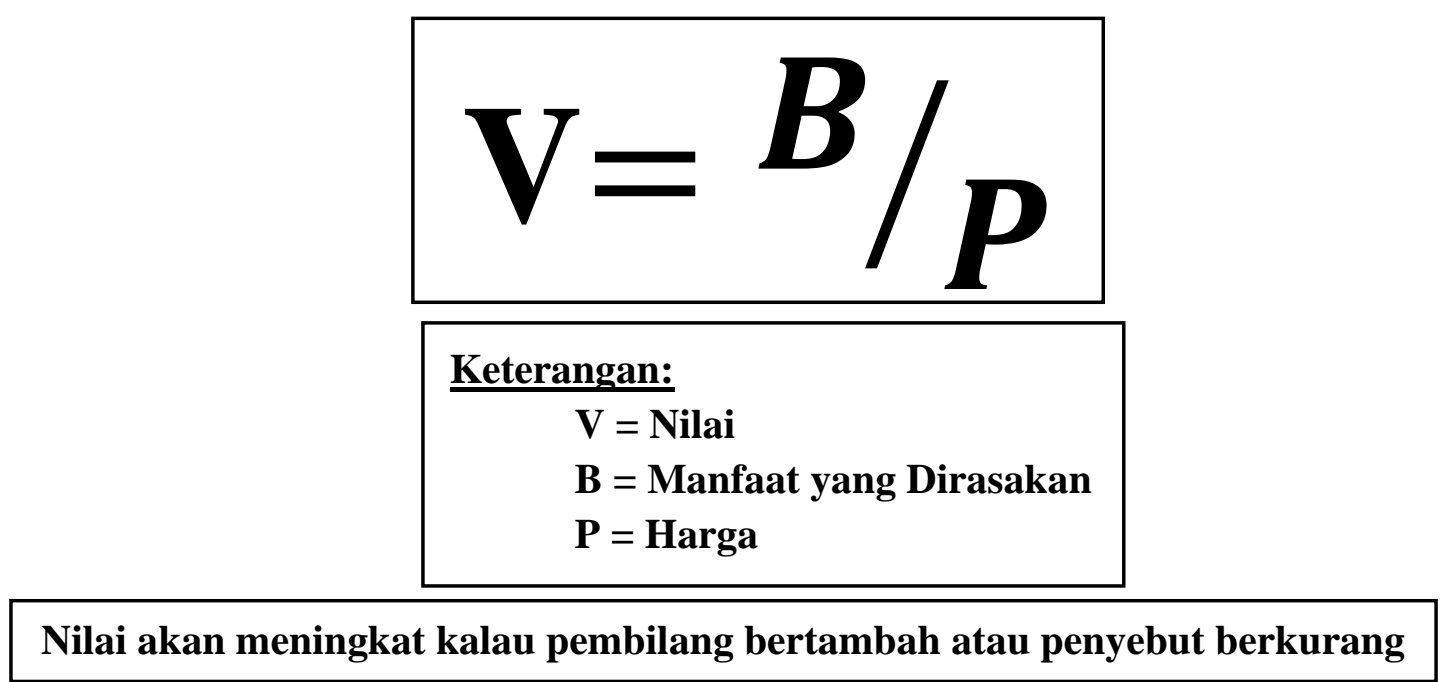

Gambar 1. Persamaan Nilai

b. Keunggulan Kompetitif dan Diferensial : Keunggulan kompetitif adalah penawaran total, dihadapkan pada persaingan yang relevan, yang lebih menarik pelanggan. Penawaran total harus lebih menarik dari yang ditawarkan oleh pesaing agar menciptakan keunggulan bersaing. Sebuah perusahaan mungkin mempunyai produk yang bermutu sama dengan produk pesaing, tetapi tidak lebih baik.

c. Fokus : Fokus diperlukan untuk berhasil dalam tugas menciptakan nilai pelanggan dalam keunggulan kompetitif. Semua perusahaan terkemuka, besar dan kecil, mengalami sukses karena mereka memahami dan menerapkan prinsip dasar ini. Fokus yang jelas pada kebutuhan dan keinginan pelanggan serta pada penawaran yang bersaing diperlukan untuk menggerakkan usaha yang perlu untuk mempertahankan keunggulan yang membedakan.

\section{Konsep Pemasaran}

Definisi pemasaran menurut Philip Kotler (1990:5-20) bertumpu pada konsep pokok sebagai berikut : kebutuhan, keinginan dan permintaan; produk; nilai (value) dan kepuasan; pertukaran atau transaksi; pasar; serta pemasaran dan pemasar.

a. Kebutuhan, keinginan dan penawaran : Suatu perbedaan yang jelas tentang pengertian kebutuhan, keinginan dan permintaan dapatlah dikemukakan sebagai berikut: "Kebutuhan manusia adalah sesutau keadaan akan sebagian dari pemuasan dasar yang dirasakan atau disadari". Keinginan manusia adalah hasrat untuk memperoleh pemuas-pemuas tertentu untuk kebutuhan yang lebih mendalam ini. Meskipun kebutuhan manusia jumlahnya sedikit, tetapi keinginan mereka banyak. Permintaan adalah keinginan terhadap produk-produk tertentu yang didukung oleh 
suatu kemampuan dan kemauan untuk membeli produk itu. Keinginan menjadi permintaan jika didukung oleh kemampuan untuk membeli.

b. Produk : produk dalam arti yang lebih luas untuk mencakup "segala suatu yang diberikan kepada seseorang guna memuaskan suatu kebutuhan atau keinginan". Sebuah obyek fisik merupakan alat untuk memberikan jasa. Pekerjaan para manajer perusahaan adalah untuk menjual maslahat atau jasa yang terkandung dalam produk, bukan semata-mata untuk menjelaskan ciri-ciri produk mereka.

c. Nilai dan Kepuasan : Ahli ekonomi abad ke-19 berpendapat bahwa nilai adalah satu konsep subyektif, bukan satu konsep obyektif. Konsumen menentukan nilai suatu produk sesuai dengan kapasitas produk itu untuk memuaskan keinginannya. Para ahli ekonomi pada abad ke-20 beranggapan bahwa konsumen hanya mempunyai kecakapan untuk menentukan tingkatan dua obyek berdasarkan mana yang lebih mereka sukai.

d. Pertukaran dan transaksi : Pertukaran merupakan salah satu cara yang dilakukan orang untuk memperoleh produk yang diinginkannya. Transaksi adalah dasar jual beli. "Transaksi terdiri dari suatu perdagangan antar nilai antar dua pihak" (Philip Kotler, 1990:14). Suatu transaksi mencakup beberapa kesatuan (entities) yang dapat diukur; paling tidak dua benda yang bernilai, syarat yang mendekati, waktu persetujuan dan tempat persetujuan.

e. Pasar : Sebuah pasar terdiri dari pelanggan potensial dengan kebutuhan atau keinginan tertentu yang mungkin mau dan mampu untuk ambil bagian dalam jual beli guna untuk memuaskan kebutuhan atau keinginan tersebut.

f. Pemasaran dan Para Pemasar : Pemasar adalah "seorang yang berusaha memperoleh sumber daya dari orang lain dan mau menawarkan sesuatu yang bernilai sebagai imbalannya." Setiap orang yang ingin menjadi pembeli akan mencoba memasarkan dirinya menjadi orang yang terpilih oleh penjual. Para pembeli ini sedang melakukan pemasaran.

\section{Manajemen Pemasaran Syariah}

Pemasaran syariah adalah sebuah disiplin busnis strategis yang mengarahkan proses penciptaan, penawaran dan perubahan value dari suatu inisiator kepada stakeholder-nya, yang dalam keseluruhan prosesnya sesuai dengan akad dan prinsip-prinsip muamalah (bisnis) dalam Islam. Dan merupakan salah satu bentuk muamalah yang dibenarkan dalam Islam, sepanjang dalam segala proses transaksinya terpelihara dari hal-hal yang terlarang oleh ketentuan syariah. (Kertajaya dan Sula, 2006).

Adapun menurut Abdullah (2006) pemasaran dalam perspektif syariah adalah segala aktivitas bisnis dalam bentuk kegiatan penciptaan nilai (vaule creating activities) yang 
memungkinkan pelakunya bertumbuh dengan mendayagunakan kemanfatannya yang dilandasi dengan kejujuran, keadilan, keterbukaan dan keikhlasan sesuai prose yang berprinsip pada akad bermuamalah islami.

\section{Manajemen Pemasaran Organisasi Nirlaba}

Menurut Philip Kotler dan Alan R. Andersen (1995:9) Organisasi Nirlaba bertujuan untuk mendukung; Pertama, keinginan individu untuk berbagi, Kedua, kebaikan untuk kesejahteraan, dan Ketiga, santunan pemerintah pusat, provinsi dan daerah.

. Henry Hansmann (1980:835-901) membagi jenis organisasi nirlaba menurut dua set ciri-ciri. Pertama apakah organisasi tersebut donatif atau komersil, yaitu apakah pendapatannya yang utama berasal dari donasi atau pembayaran dari pengguna. Kedua apakah organisasi tersebut mutual atau entrepreneurial. Organisasi mutual terutama dikendalikan oleh pengguna, sedangkan organisasi enterpreneuial dikendalikan oleh manajer profesional.

\section{Lembaga Amil Zakat}

pengertian LAZ menurut Pasal 1 Ayat (8) UU NO.23 Tahun 2011 Tentang Pengelolaan Zakat menyebutkan bahwa : "Lembaga Amil Zakat yang selanjutnya disingkat LAZ adalah lembaga yang dibentuk masyarakat yang memiliki tugas membantu pengumpulan, pendistribusian, dan pendaya gunaan zakat". Pada Pasal 17 dijelaskan maksud dan tujuan pendirian LAZ, yakni : "Untuk membantu BAZNAS dalam pelaksanaan pengumpulan, pendistribusian, dan pendayagunaan zakat, masyarakat dapat membentuk LAZ”.

\section{Prinsip Pengelolaan}

Prof. H.A. Djazuli dan Drs. Yadi Janwari, M.Ag (2002:45-47) mengemukakan pengelolaan Lembaga Amil Zakat beberapa prinsip yang harus diikuti dan ditaati agar pengelolaan itu dapat berhasil guna sesuai dengan yang diharapkan.

a. Prinsip keterbukaan : artinya dalam pengelolaan zakat, infaq dan Shadaqah hendaknya dilakukan secara terbuka dan diketahui oleh masyarakat hukum.

b. Prinsip sukarela : berarti bahwa dalam pemungutan dan pengumpulan ZIS, Lembaga Amil Zakat hendaknya senantiasa berdasar pada prinsip sukarela dari ummat Islam yang menyerahkan harta ZIS dan tidak boleh ada unsur pemaksaan atau cara-cara yang dapat dianggap sebagai suatu pemaksaan.

c. Prinsip keterpaduan; Lembaga Amil Zakat sebagai organisasi yang berasal dari swadaya masyarakat dalam menjalankan tugas dan fungsinya mesti dilakukan secara terpadu di antara komponen-komponennya. 
d. Prinsip profesionalisme : berarti bahwa dalam pengelolaan zakat, infaq dan shadaqah harus dilakukan oleh mereka yang ahli di bidangnya, baik dalam administrasi, keuangan dan lain sebagainya.

e. Prinsip Kemandirian : Lembaga Amil Zakat diharapkan menjadi Lembaga Swadaya Masyarakat yag mandiri dan mampu melaksanakan tugas dan fungsinya sendiri tanpa perlu menunggu bantuan dari pihak lain.

\section{METODE PENELITIAN}

Metode penelitian yang digunakan adalah deskriptif kualitatif dengan mengolah data yang didapatkan dari hasil penelitian lapangan berupa hasil wawancara dan dokumen lembaga. Data yang didapatkan kemudian dianalisis berpedoman dengan tinjauan teoritis yang telah penulis sebutkan diatas. Dengan metode ini lebih memudahkan penulis untuk mengambil kesimpulan.

\section{HASIL DAN ANALISIS}

\section{Profil dan sejarah singkat Baitul Maal Hidayatullah}

Lembaga Amil Zakat Nasional Baitul Maal Hidayatullah (BMH) Merupakan lembaga amil zakat yang bergerak dalam penghimpunan dana Zakat, infaq, sedekah, Wakaf dan Hibah berikut dana sosial kemanusiaan dan Corporate Social Responsibility (CSR) perusahaan, dan melakukan distribusi melalui program pendidikan, dakwah, sosial kemanusiaan dan ekonomi secara nasional.

Berdirinya LAZNAS (Lembaga Amil Zakat Nasional) BMH (Baitul Maal Hidayatullah) tidaklah terlepas dari akar sejarah Pesantren Hidayatullah yang awal mula didirikan pada tanggal 7 Januari 1973 (2 Dzulhijjah 1392 Hijriah) di Balikpapan oleh Ust. Abdullah Said (alm), kemudian berkembang dengan berbagai amal usaha di bidang sosial, dakwah, pendidikan dan ekonomi termasuk salah satunya amal usaha yang melakukan kegiatan penghim-punan, pengelolaan dan pendayagunaan dana ZISWAF dalam sebuah lembaga yang kemudian diberi nama Baitul Maal Hidayatullah.

Seiring pertumbuhan dan perkembangan Pesantren Hidayatullah yang mencapai 283 cabang di seluruh Indonesia, dan telah ditetapkannya UU Nomor 38 tahun 1999 mengenai regulasi pengelolaan zakat, maka pada tanggal 27 Desember 2001 Baitul Maal Hidayatullah mendapatkan pengukuhan (legalitas) operasional dari Kementerian Agama RI sebagai Lembaga Amil Zakat Nasional (LAZNAS).

\section{Manajemen Pemasaran Baitul Maal Hidayatullah}

Baitul Maal Hidayatullah (BMH) memiliki manajer marketing (pemasaran) di setiap branch (cabang) yang dikordinasikan langsung oleh Direktur Penghimpunan dan Komunikasi dari pusat. Masing-masing manajer bertugas mengelola program-program serta layanan yang 
dimiliki oleh BMH. Tiap branch (cabang) Baitul Maal Hidayatullah memiliki staf-staf marketing serta relawan yang terbagi ke 3 divisi :

1. Direct Marketing : Terdiri dari tenaga ahli marketing berpengalaman yang bertugas mempresentasikan program-program BMH ke perusahaan-perusahaan patner, juga para relawan yang menjaga stand-stand dan yang disebar selama Bulan Ramadhan untuk melakukan door to door/personal selling.

2. E-Marketing : Para staff marketing yang bertugas untuk mendevelope syiar-syiar zakat melalui media online, mulai dari website yang dikendalikan langsung oleh staff emarketing pusat yang juga bertanggung jawab menjawab pertanyaan-pertanyaan dan menjelaskan kepada muzakki tentang kewajiban zakat.

3. Tele-marketing : Staff serta relawan yang setia memberikan update program-program terbaru BMH melalui layanan telephone kepada para donatur/Muzakki.

Untuk program di BMH dibingkai dalam beberapa bidang. Yang pertama dakwah, yang kedua pendidikan, yang ketiga adalah program sosial-ekonomi, yang keempat adalah program kemanusiaan.

1. Dakwah : Bidang ini ada turunan beberapa kegiatan/program adalah penyebaran da'i dengan tujuan bagaimana bisa mencerahkan masyarakat untuk lebih dekat kepada agamanya (khususnya msyarakat muslim yang ada di pedalaman). Program bidang dakwah antara lain 1). Natura Da'i, 2) Da'i Pemberdaya 3) Umroh Da'i, 4) Kesehatan da'i, 5) Fasilitas Da'i (kendaraan roda dua).

2. Pendidikan : BMH punya program beasiswa tahfizh yang diberikan kepada santri tahfizh karena mereka termasuk ashnaf yang berhak menerima zakat dari kelompok Fi Sabilillah (karena menuntut ilmu). Selanjutnya ada program beasiswa anak indonesia, bagi anakanak yang berada di pedalaman dan berprestasi diberikan beasiswa dari dana ZISWAF untuk mereka melanjutkan pendidikannya ke jenjang yang lebih tinggi.

3. Sosial-Kemanusiaan : Bidang sosial menyasar bagaimana penyaluran dana BMH itu semakin banyak manfaatnya di masyarakat, khususnya masyarakat yang memang berhak menerima zakat. Sedangkan program kemanusiaan adalah program yang diusung ketika terjadi bencana seperti gempa di Ambon, kerusuhan Wamena dan beberapa daerah yang juga mengalami bencana.

4. Ekonomi : Bidang ekonomi ini lebih fokus kepada kebutuhan konsumtif penerima manfaat serta kebutuhan pemberdayaan, untuk kebutuhan pemberdayaan Baitu Maal Hidayatullah telah memiliki bebepa program yang memang diciptakan agar supaya program pemberdayaan ini dirasakan oleh masyarakat. 


\section{Analisis}

Berdasarkan hasil penelitian yang penulis telah lakukan melalui pengumpulan data berupa wawancara, dokumen (Annual Report/Laporan Tahunan Baitul Maal Hidayatullah 2018) dan foto-foto dokumentasi kegiatan program yang dijalankan oleh Baitul Maal Hidayatullah. Maka penulis melalukan analisis berdasarkan hasil penelitian tersebut.

Manajemen Pemasaran di Baitul Maal Hidayatullah bila ditinjau dari program-program yang mereka miliki telah menerapkan prinsip analisis, perencanaan, penerapan serta pengendalian dari program itu sendiri. Program yang dibuat telah melewati proses analisis untuk melihat tujuan dan manfaatnya, serta memperhatikan ketertarikan donatur/muzakki untuk berkontribusi mensukseskan program tersebut. Mereka juga telah membuat sistem perencanaan yang mumpuni sehingga dana yang terkumpul tersalurkan dengan baik dan tepat sasaran langsung kepada pihak-pihak yang membutuhkan. karena Baitul Maal Hidayatullah telah memetakan target-target penyaluran serta bekerja sama dengan pihak-pihak terkait untuk mensukseskan program tersebut sesuai dengan definisi langkah-langkah yang harus dilakukan dalam kegiatan perencanaa pemasaran.

Namun dengan luasnya jangkauan program yang dijalankan sedikit menyulitkan Baitul Maal Hidayatullah untuk menjalankan proses pengendalian, salah satunya terlihat dari faktor penghambat. Kurangnya kesadaran dari penerima manfaat untuk mau memberikan laporan secara rutin terkait dengan apa yang mereka terima dari Baitul Maal Hidayatullah. Contohnya dalam program pemberdayaan masih menjadi kendala ketika supervisi yang diberikan tidak intensif, penerima manfaat masih harus terus-menerus diedukasi. Baitul Maal Hidayatullah terlihat kewalahan mengelola dana yang telah tersalurkan dalam hal pelaporan kepada donatur/muzakki kurangnya relawan yang melakukan pendampingan serta terbatasnya waktu membuat progarm (khususnya program 'Mandiri Terdepan') kurang terlihat progresnya di mata para donatur/muzakki dan hal itu sedikit banyak berpengaruh pada kepercayaan mereka.

Dalam kegiatan pemasaran yang ideal, pemasaran di lingkungan pasar pelanggan dilaksanakan oleh manajer penjualan, perwakilan penjulalan, manajer periklanan dan promosi, para peneliti di bidang pemasaran, manajer urusan jasa pelanggan, manajer produk, manajer pasar dan wakil pemasaran (Philip Kotler, 1990:20). Tapi pada faktanya dengan keterbatasan jumlah SDM yang dimiliki kegiatan di atas dibebankan seluruhnya kepada staff pemasaran serta relawan yang membantu mereka. Hal tersebut menyebabkan kegiatan pemasaran di Baitul Maal Hidayatullah tidak berjalan bisa berjalan secara efisien/maksimal dan mengurangi kefektifan program yang sedang berlangsung.

Philip Kotler dan Alan R. Andersen (1995:8) menegaskan bahwa Manajer Pemasaran yang sesungguhnya adalah orang yang tahu persepsi yang benar dari falsafah pemasaran, juga tahu pendekatan yang komprehensif dan praktis dalam memecahkan masalah-masalah pemasaran, serta sadar dan memahami alat dan teknik yang dapat dipakai dalam pemasaran yang efektif. Tapi fakta dilapangan menunjukkan Manajer Pemasaran yang ada masih terlalu 
mengandalkan pengalaman dan insting yang dipunya dan beberapa dari mereka baru mulai mengambil pendidikan manajmene pemasaran di tingkat lanjut (S2).

Pembahasan terakhir adalah inti dari keberadaan Baitul Maal Hidayatullah sebagai Lembaga Amil Zakat berdasarkan Pasal 1 Ayat (8) UU No. 23 Tahun 2011 Tentaang Pengelolaan Zakat adalah lembaga yang dibentuk masyarakat yang memiliki tugas membantu pengumpulan, pendistribusian, dan pendayagunaan zakat. Fungsi utama Lembaga Amil Zakat adalah sebagai wadah pengelola penerimaan, pengumpulan, penyaluran dan pendayagunaan zakat, infaq dan shadaqah dalam rangka peningkatan kesejahteraan masyarakat sebagai wujud partisipasi ummat Islam dalam pembangunan nasional, Lembaag Amil Zakat juga berfungsi sebagai pembinaaan dan pengembangan swadaya masyarakat (Prof. H.A. Djazuli dan Drs. Yadi Janwari, M.Ag, 2002:48). Fungsi di atas, terutama fungsi utama merupakan suatu hal yang masih harus terus dikuatkan khususnya di Manajemen Pemasaran Baitul Maal Hidayatullah, agar program-program yang dibuat benar-benar terarah pada usaha untuk mengentaskan kemiskinan dan mencapai tujuan utama dari ekonomi Islam, yakni tercapainya Falah (kesejahteraan) bagi seluruh ummat Islam pada khususnya dan ummat manusia pada umumnya.

Selanjutnya, pemahaman dan pengertian para staf dan relawan khususnya di bidang marketing perlu ditingkatkan. Mengerti dan memahami hukum-hukum zakat yang akan menyebabkan ia mampu melakukan sosialisasi segala sesuatu yang berkaitan dengan zakat kepada masyarakat. Dengan pengetahuan tentang zakat yang relatif memadai, para amil zakat diharapkan terbebas dari kesalahn dan kekeliruan yang diakibatkan dari kebodohan pada masalah zakat tersebut. Pengetahuan tentang zakat ini pun akan mengundang kepercayaan dari masyarakat.

\section{KESIMPULAN}

Baitul Maal Hidayatullah butuh merekrut lebih banyak tenaga profesional agar beban berlebih yang ditanggung para manajer dan staff pemasaran bisa berkurang dan potensi kreatifitas mereka bisa dimaksimalkan. Dan dilapangan perlu relawan tambahan untuk memberikan pendampingan agar manfaat (dana/bantuan) yang diterima bisa meningkatkan taraf hidup mereka.

\section{DAFTAR PUSTAKA}

Abdullah, 2006, Asuransi Syariah, PT Elex Media Komputindo, Jakarta.

Al-Qurthubi, (1413 H / 1993M) al-Jami'Li Ahkam al-Qur'an, Beirut Lebanon, Daar el-Kutub 'ilmiyyah, M. Jilid VII-VIII, hlm. 112-113

Al-Shan'ani, Ismail al-Kahlani, Subulus-Salam Dahlan, Bandung, tt, Juz II.

Djazuli, Ahmad dan Yadi Janwari, 2002 LEMBAGA-LEMBAGA PEREKONOMIAN UMMAT (Sebuah Pengenalan), PT. Raja Grafindo Persada, Jakarta.

Hansmann, Henry, 1980 The Role of Nonprofit Enterprises, The Yale and Law Journal.

Keegan, Warren J., 1996, MANAJEMEN PEMASARAN GLOBAL, Andi Offest, Jakarta. 
AL-INFAQ: Jurnal Ekonomi Islam, (p-ISSN: 2087-2178, e-ISSN: 2579-6453)

Vol. 11 No. 1 (2020)

Kertajaya, Hermawan dan Muhammad Syakir Sula. 2006. Syariah Marketing. PT Mizan Pustaka, Bandung.

Kotler, Philip, 1990, MARKETING MANAGEMENT analysis, planning, and control, PT Gelora Aksara Pratama, Jakarta.

Kotler, Philip dan Alan R. Andersen, 1995, STRATEGI PEMASARAN UNTK ORGANISASI NIRLABA, GAJAH MADA UNIVERSITY PRESS, Yogyakarta

Maulana, Amalia E. 2010. Pemasaran Sosial: MarCom Gaya, LAZ. ETNOMARK. 